\title{
Profil Tingkat Keparahan Retinopati Diabetik Dengan Atau Tanpa Hipertensi pada di RSUP Dr. M. Djamil Padang
}

\author{
Putri Nirmala Dewi ${ }^{1}$, Fadrian $^{2}$, Havriza Vitresia ${ }^{3}$
}

\begin{abstract}
Abstrak
Retinopati diabetik merupakan komplikasi mikrovaskular dari Diabetes Melitus (DM) berupa mikroangiopati progresif yang ditandai oleh kerusakan mikrovaskular pada retina. Retinopati diabetik menempati urutan ke-4 sebagai penyebab kebutaan secara global setelah katarak, glukoma, dan degenerasi makula. Terdapat berbagai faktor yang memengaruhi derajat keparahan retinopati diabetik seperti hiperglikemia, lama durasi DM, dan hipertensi. Tujuan penelitian ini adalah mengetahui profil tingkat keparahan retinopati diabetik dengan atau tanpa hipertensi pada pasien diabetes melitus di RSUP Dr. M. Djamil Padang. Jenis penelitian ini adalah deskriptif observasional retrospektif dengan menggunakan data sekunder, yaitu rekam medik pasien retinopati diabetik di RSUP Dr. M. Djamil Padang periode Januari-Desember 2016. Data diolah menggunakan microsoft excel dan analisis data disajikan melalui analisis univariat. Populasi untuk penderita diabetes melitus sebanyak 1500 orang dengan penderita retinopati diabetik sebanyak 187 orang (12,5\%) dan yang memenuhi kriteria inklusi sebanyak 162 orang. Hasil penelitian berdasarkan karakteristik penderita menurut usia terbanyak pada usia 45-65 tahun yaitu 129 orang $(79,6 \%)$, menurut jenis kelamin lebih banyak pada laki-laki yaitu 87 orang $(53,7 \%)$, menurut durasi menderita DM lebih banyak pada penderita $>5$ tahun sebesar 110 orang (68\%), menurut ada tidaknya dislipdemia lebih banyak pada penderita dengan dislipdemia sebanyak 116 orang $(71,7 \%)$. Profil tingkat keparahan retinopati diabetik terbanyak ada pada pasien dengan hipertensi pada stadium retinopatidiabetik proliferative sebanyak 56 orang $(69,6 \%)$.
\end{abstract}

Kata kunci: retinopati diabetik, hipertensi, diabetes mellitus

\section{Abstract}

Diabetic retinopathy is a complication from diabetes as progressive microangiopathy causing microvascular damage on retina. Diabetic retinopathy is placed the 4th most prevalence cause of global blindness following cataract, glaucoma and age-related macular degeneration. Factors influencing the severity of diabetic retinopathy are hyperglycemic state, duration of sickness and hypertension. The objective of this study was to assess the severity of diabetic retinopathy on patients with and without having hypertension in DR. M. Djamil General Hospital. An observational descriptive study was done with retrospective approach by using medical records of patient in Dr. M. Djamil Padang General Hospital on Januari until December 2016. Data was processed by microsoft excel and presented as univariate analysis. Population of diabetes mellitus patients was 1500 from which 187 (12.5\%) had diagnosed with diabetic retinopathy and had been sorted out to 162 based on inclusion criteria. The study showed that 129 patients were 45 - 65 years old (79.6\%), 87 patients were men (53.7\%), 110 patients had diabetes > 5 years (68 $\%), 116$ patients also had dyslipidemia as co-morbid (71.7\%) and 47 patients having hypertension were in severe stadium of diabetic retinopathy with Proliferative Diabetic Retinopathy (84 \%).

Keywords: diabetic retinopathy, hypertension, diabetes mellitus

Affiliasi penulis: 1. Prodi Kedokteran Fakultas Kedokteran Universitas Andalas Padang (FK Unand) 2. Bagian IImu Penyakit Dalam FK Unand/RSUP Dr. M. Djamil Padang 3.Bagian IImu Kesehatan Mata FK Unand/RSUP Dr. M. Djamil Padang
Korespondensi :Putri Nirmala Dewi, Email: punirmala@gmail.com, Telp: 081276053415 


\section{PENDAHULUAN}

Diabetes melitus (DM) adalah penyakit metabolisme yang ditandai dengan meningkatnya kadar gula darah dalam tubuh yang disebabkan oleh resistensi insulin atau gangguan produksi insulin. ${ }^{1}$ Diabetes merupakan penyakit kronis yang banyak diderita oleh masyarakat Indonesia. Menurut data dari International Diabetes Federation (IDF) pada tahun 2011 terdapat 355 juta orang di dunia yang terdiagnosis DM, angka ini diperkirakan akan terus meningkat dan mencapai 552 juta jiwa pada tahun $2030 .{ }^{2}$ Prevalensi DM di Indonesia sebesar 6,9\% pada populasi penduduk usia $\geq 15$ tahun. Terdapat 3.427.772 jiwa atau 1,8\% jumlah penduduk usia $\geq 15$ tahun yang menderita diabetes melitus di Sumatera Barat, sedangkan menurut jenis kelamin angka kejadian DM lebih tinggi pada wanita dibandingkan laki-laki. ${ }^{3}$

Kondisi hiperglikemia yang berkepanjangan pada DM dapat menyebabkan berbagai komplikasi baik makrovaskular dan mikrovaskular. Salah satu komplikasi mikrovaskular yang tersering adalah retinopati diabetik. Penyakit ini menyebabkan turunnya fungsi penglihatan karena adanya gangguan pada fungsi retina yang berpotensi tinggi menyebabkan kebutaan. ${ }^{4}$ Retinopati diabetik menempati urutan ke-4 sebagai penyebab kebutaan secara global setelah katarak, glukoma, dan degenerasi makula (age related macular degeneration). Kelompok umur yang paling sering mengalami komplikasi ini adalah rentang umur 20-64 tahun. ${ }^{5}$ Komplikasi tersering pada mata dan menjadi penyebab kebutaan pada pasien DM adalah retinopati diabetic tipe proliferatif.iskemia pada retina yang terjadi terus-menerus sehingga menyebabkan pembentukan pembuluh darah baru di sekitar retina yang menyebabkan kebocoran protein serum. ${ }^{6}$

Penelitian yang dilakukan oleh Chennai Urban Population Study (CUPS) menyatakan bahwa prevalensi hipertensi pada pasien DM sebesar 46,7\% yaitu tiga kali lipat lebih banyak dibandingkan dengan orang yang hanya menderita hipertensi saja sebesar $16,7 \%$. $^{7}$

Studi yang dilakukan oleh Wisconsin Epidemiologic Study of Diabetic Retinopathy (WESTDR) menunjukkan prevalensi hipertensi pada pasien DM tipe 1 adalah $17,3 \%$ dan meningkat menjadi 25,9\% setelah 10 tahun. $^{8}$

Penelitian United Kingdom Prospective Diabetes Study (UKPDS) menunjukkan hubungan yang signifikan antara tekanan darah sistolik dengan retinopati diabetik pada pasien DM tipe 2, dimana penderita DM dengan tekanan darah sistolik $\geq 140$ $\mathrm{mmHg}$ memiliki risiko perburukan retinopati diabetik 2,8 kali dibandingkan dengan pasien DM dengan tekanan darah sistolik $<125 \mathrm{mmHg}^{9}$

\section{METODE}

Jenis penelitian ini adalah deskriptif observasional retrospektif untuk mengetahui profil tingkat keparahan retinopati diabetic dengan atau tanpa hipertensi pada pasien DM di RSUP Dr. M. Djamil Padang. Penelitian ini dilakukan di Bagian Rekam Medik RSUP Dr. M. Djamil Padang. Penelitian ini dilaksanakan selama 2 bulan. Populasi penelitian ini adalah seluruh data rekam medik pasien DM yang mengalami retinopati diabetik di bagian rekam medik RSUP Dr. M. Djamil Padang antara Januari sampai Desember 2016. Sampel penelitian ini adalah semua populasi yang telah memenuhi kriteria Inklusi dan ekslusi. Kriteria inklusi adalah responden dengan retinopati diabetik dengan hasil pemeriksaan tekanan darah lengkap yang terdapat dalam rekam medik RSUP Dr. M. Djamil Padang antara Januari sampai Desember 2016. Kriteria ekslusi adalah responden dengan retinopati diabetik dengan data yang tidak lengkap atau tidak ada. Teknik pengambilan sampel adalah total sampling. Data disajikan dengan mendistribusikan melalui analisis univariat. Analisis univariat dilakukan terhadap tiap variable dari hasil penelitian. Tujuan danalisis ini untuk menghasilkan distribusi dan persentase dari tiap variabel.

\section{HASIL}

Berdasarkan penelitian yang telah dilakukan secara deskriptif tentang profil tingkat keparahan retinopati diabetik pada pasien diabetes melitus dengan atau tanpa hipertensi di bagian Poli Khusus Endokrin Penyakit Dalam dan Poli Kesehatan Mata RSUP Dr. M. Djamil Padang Periode Januari sampai Desember 2016 didapatkan 1500 pasien diabetes 
melitus dengan pasien yang menderita retinopati diabetik sebanyak 187 orang (12,5\%). Pasien yang memenuhi kriteria inklusi adalah 162 orang. Jumlah sampel penelitian adalah 102 untuk pasien dengan hipertensi dan 60 untuk pasien tanpa hipertensi. Sebanyak 25 sampel diekslusikan karena data rekam medik yang tidak lengkap atau tidak ada.

\section{Distribusi Frekuensi Karakteristik Subjek Sampel Penelitian}

Distribusi frekuensi karakteristik subjek sampel penelitian adalah sebagai berikut:

Tabel 1. Distribusi frekuensi karakteristik subjek sampel penelitian

\begin{tabular}{lc}
\hline \multicolumn{1}{c}{ Karakteristik Subjek } & $\mathbf{n}$ \\
\hline Usia (tahun) & 15 \\
$<45$ & 129 \\
$45-65$ & 18 \\
$>65$ & \\
JenisKelamin & 87 \\
Laki-laki & 75 \\
Perempuan & \\
DurasimenderitaDM & \\
$\quad \leq 5$ tahun & 52 \\
$\quad>5$ tahun & 110 \\
Tekanandarah & \\
$\quad$ Hipertensi & 102 \\
$\quad$ Tidakhipertensi & 60 \\
Dislipidemia & Ada \\
$\quad$ Tidak & 116 \\
$\quad$ Total & 46 \\
\hline
\end{tabular}

Berdasarkan Tabel 1 diketahui bahwa pasien retinopati diabetik di RSUP Dr M Djamil Padang terbanyak pada usia 45 sampai 65 tahunyang berjumlah 129 orang $(79,6 \%)$, penderita dengan jenis kelamin laki-laki memiliki jumlah sedikit lebih banyakdari perempuan yaitu 87 orang $(53,7 \%)$, durasi menderita DM terbanyak pada > 5 tahun sebanyak 110 orang (68\%), penderita dengan hipertensi berjumlah 103 orang $(63,5 \%)$, dan penderita dengan dislipidemia berjumlah 116 orang $(71,7 \%)$.
Distribusi Frekuensi Tingkat Keparahan Retinopati Diabetik Pada Pasien Diabetes Melitus

Distribusi frekuensi tingkat keparahan retinopati diabetik pada pasien diabetes melitus adalah sebagai berikut:

Tabel 2. Distribusi frekuensi tingkat keparahan retinopati diabetik pada pasien diabetes melitus

\begin{tabular}{lcc}
\hline \multicolumn{1}{c}{ Derajat } & n & $\%$ \\
\hline NPDR & 106 & 65,4 \\
Mild & 43 & 26,5 \\
Moderate & 38 & 23,4 \\
Severe & 25 & 15,4 \\
PDR & 56 & 34,5 \\
\hline Total & 162 & 100 \\
\hline
\end{tabular}

Pada Tabel 2 diatas didapatkan distribusi frekuensi tingkat keparahan retinopati diabetik pada pasien DM di RSUP Dr. M. Djamil Padang terbanyak adalah NPDRyang berjumlah 106 orang (65,4\%) dengan tingkat keparahan untuk mild NPDR berjumlah 43 orang $(26,5 \%)$, moderate NPDR berjumlah 38 orang $(23,4 \%)$, severe NPDR berjumlah 25 orang (15,4\%), sedangkan untuk pasien PDR berjumlah 56 orang (34,5\%).

\section{Distribusi Frekuensi Pasien Retinopati Diabetik Dengan Atau Tanpa Hipertensi}

Distribusi frekuensi pasien retinopati diabetik dengan atau tanpa hipertensi adalah sebagai berikut:

Tabel 3. Distribusi frekuensi pasien retinopati diabetik dengan atau tanpa hipertens

\begin{tabular}{ccc}
\hline Hipertensi & $\mathbf{N}$ & $\%$ \\
\hline Ada & 102 & 62,9 \\
Tidak & 60 & 37,1 \\
\hline Total & 162 & 100 \\
\hline
\end{tabular}

Berdasarkan Tabel 3 didapatkan distribusi frekuensi pasien retinopati diabetik dengan hipertensi pada pasien DM di RSUP Dr. M. Djamil Padang sebanyak 102 orang (62,9\%). Sementara itu, pasien yang tidak menderita hipertensi sebanyak 
60 orang $(37,1 \%)$, sehingga dapat disimpulkan bahwa pasien retinopati diabetik yang menderita hipertensi lebih banyak dibandingkan pasien tanpa hipertensi.

\section{Distribusi Frekuensi Hipertensi Berdasarkan}

\section{Tingkat Keparahan Retinopati Diabetik}

Distribusi frekuensi hipertensi berdasarkan tingkat keparahan retinopati diabetik adalah sebagai berikut:

Tabel 4. Distribusi frekuensi hipertensi berdasarkan tingkat keparahan retinopati diabetik

\begin{tabular}{lcccc}
\hline $\begin{array}{c}\text { Tingkat } \\
\text { Keparahan } \\
\text { Retinopati } \\
\text { Diabetik }\end{array}$ & Hipertensi & Tidak Hipertensi \\
\hline & $\mathbf{n}$ & $\%$ & $\mathbf{n}$ & $\%$ \\
\hline Mild NPDR & 25 & 24,5 & 18 & 30 \\
Moderate & 23 & 22,5 & 15 & 25 \\
NPDR & 15 & 14,7 & 10 & 16,7 \\
Severe & 39 & 37,3 & 17 & 28,3 \\
NPDR & 102 & 100 & 60 & 100 \\
PDR & & &
\end{tabular}

Pada Tabel 4 berdasarkan tingkat keparahan retinopati diabetik didapatkan distribusi frekuensi hipertensi terbanyak ada pada penderita retinopati diabetik stadium PDR sebanyak 39 orang (37,3\%), sedangkan pada pasien yang tidak menderita hipertensi tingkat keparahan retinopati diabetik terbanyak ada pada pasien mild NPDR sebanyak 18 orang (30\%).

\section{Profil Tingkat Keparahan Retinopati Diabetik Dengan Atau Tanpa Hipertensi}

Profil tingkat keparahan retinopati diabetik dengan atau tanpa hipertensi adalah sebagai berikut:

Gambar 1 menunjukkan bahwa pada pasien dengan hipertensi ditemukan tingkat keparahan retinopati diabetik yang berbeda-beda,yaitumild NPDR sebesar58,1\%,moderate NPDR sebesar60,5\%, severe NPDR sebesar $60 \%$ dan PDR sebesar $69,6 \%$, sedangkanuntuk pasien retinopati diabetik tanpa hipertensi ditemukantingkat keparahan retinopati diabetik dengan persentase yang lebih kecil yaitu mild NPDR sebesar 41,9\%, moderate NPDR sebesar $39,5 \%$, severe NPDR sebesar40\%, dan PDR sebesar $30,4 \%$. Hal ini menunjukkan pasien dengan tingkat keparahan PDR lebih banyak yang menderita hipertensi.

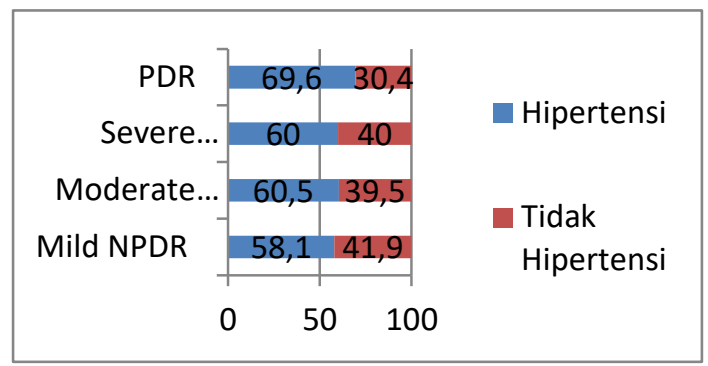

Gambar1. Profil tingkat keparahan retinopati diabetik dengan atau tanpa hipertensi

\section{PEMBAHASAN}

Berdasarkan penelitian yang dilakukan pada pasien retinopati diabetik di RSUP Dr. M. Djamil Padang periode Januari sampai Desember 2016 diperoleh hasil seperti pada tabel 5.1 dapat dilihat karakteristik subjek penelitian dari jumlah sampel yang memenuhi kriteria inklusi sebesar 162 orang, sebagian besar penderita retinopati diabetik berusia 45 sampai 65 tahun, hanya sedikit pasien yang berusia kurang dari 45 tahun dan lebih dari 65 tahun. Hal ini sesuai dengan penelitian yang dilakukan oleh Al-Sarraf et al pada tahun 2003 yang melaporkan kejadian tersering retinopati diabetik terdapat pada usia 50 sampai 59 tahun, lalu menurun di usia 60 tahun. Berbagai faktor resiko pada pasien DM seperti hiperglikemia, reaksi inflamasi, dan stres oksidatif mempercepat terjadinya apoptosis di sel retina yang mengakibatkan terjadinya retinopati diabetik. ${ }^{10}$

Angka kejadian retinopati diabetik yang rendah untuk usia kurang dari 45 tahun.Rekomendasi umur untuk memulai screening DM menurut American Diabetes Association (ADA) adalah 45 tahun. Waktu perjalanan penyakit yang cukup lama dan rerata usia penderita yang cukup tua baik saat menderita atau saat terdiagnosa menjadi faktor yang menyebabkan hanya sebagian kecil penderita yang terdiagnosa retinopati diabetik dengan usia $<45$ tahun. ${ }^{11}$ 
Pada Tabel 1 didapatkan distribusi penderita retinopati diabetik berdasarkan jenis kelamin, dimana laki-laki sedikit lebih banyak dibandingkan perempuan yaitu 87 orang (53,7\%). Penelitian Semeraro et al melaporkan kejadian retinopati lebih sering pada lakilaki yaitu $60 \% .^{12}$ Menurut WESDR, jenis kelamin lakilaki adalah faktor resiko independen dalam perkembangan retinopati diabetik. ${ }^{8}$

Berdasarkan durasi menderita DM, penderita dengan durasi lebih dari 5 tahun menderita retinopati diabetik lebih banyak yaitu berjumlah 110 orang (68\%). Lama menderita DM berperan penting dalam memprediksi terjadinya retinopati diabetik. Hal ini sesuai dengan penelitian yang dilakukan oleh AlSarraf et al menunjukkan bahwa pasien yang telah menderita DM selama 10-19 tahun memiliki resiko terkena retinopati diabetic dua kali lebih tinggi, dan meningkat menjadi tiga kali lipat setelah 20 tahun. $^{10}$ Penelitian yang dilakukan oleh Wisconsin Epidemiological Study of Diabetic Retinopathy (WESDR) menunjukkan bahwa prevalensi pasien DM yang menderita retinopati diabetik sebesar $8 \%$ setelah 3 tahun menderita DM, lalu meningkat menjadi 25\% setelah 5 tahun, $60 \%$ setelah 10 tahun, dan $80 \%$ setelah 15 tahun. Kondisi hiperglikemia yang berkepanjangan memicu terbentuknya banyak radikal bebas seperti advanced glycation end (AGE) product, sorbitol dan reactive oxygen species yang diinduksi oleh glukosa darah berlebih dalam tubuh penderita diabetes. Radikal bebas ini akan menimbulkan gangguan sirkulasi, hipoksia dan inflamasi retina. ${ }^{8}$

Tabel 1 menunjukkan pasien retinopati diabetik di RSUP Dr. M. Djamil Padang lebih banyak yang menderita dislipidemia yang berjumlah 116 orang (71,7\%). Penelitian yang dilakukan oleh Tung et al pada tahun 2005 melaporkan bahwa terdapat hubungan peningkatan trigliserida dengan kejadian retinopati diabetik. Penempelan trigliserida pada membran sel sehingga menyebabkan kerusakan diduga menjadi mekanisme dislipidemia dengan retinopati diabetik. Hal ini menyebabkan kebocoran plasma ke jaringan retina yang dapat menyebabkan perdarahan dan edema retina. ${ }^{13}$

Berdasarkan sajian Tabel 2 didapatkan derajat retinopati diabetik terbanyak pada pasien yang berobat ke RSUP Dr. M. Djamil Padang adalah PDR, lalu diikuti oleh mild NPDR, moderate NPDR, lalu severe NPDR. Hal ini berbeda dengan hasil penelitian yang dilakukan oleh Ilery et al pada tahun 2013 yang melaporkan kejadian terbanyak ada pada derajat mild NPDR. Perbedaan hasil ini kemungkinan karena pada stadium mild NPDR biasanya belum terlalu memengaruhi fungsi penglihatan penderita sehingga penderita belum memeriksakan diri ke fasilitas kesehatan dan akhirnya berkembang menjadi lebih parah.. Terjadinya kerusakan pembuluh darah di retina banyak disebabkan oleh berbagai faktor, seperti kontrol glikemik pasien DM, obesitas, hipertensi dan durasi menderita DM. ${ }^{14}$

Menurut penelitian Harnita pada tahun 2013 yang menyebutkan bahwa pasien dengan mild NPDR sudah ditemukan pada lima tahun pertama menderita DM dan derajat keparahannya akan terus meningkat dengan semakin lamanya seseorang menderita DM. Sementara itu, di RSUP Dr. M. Djamil Padang sebagian besar pasien sudah menderita DM lebih dari lima tahun yang sehingga perkembangan penyakit telah lebih progresif dan banyak yang terdiagnosa dengan stadium PDR. ${ }^{15}$

Pada Tabel 3 dan 4, serta Gambar 1 didapatkan pasien retinopati diabetik dengan hipertensi sebanyak 102 orang (62,9\%) dan yang tidak hipertensi sebanyak 62 orang $(37,1 \%)$ dengan tingkat keparahan terbanyak pada stadium PDR sebesar $69,6 \%$ dan terkecil pada mild NPDR sebesar 58,1\%.. Hal ini sesuai dengan penelitian yang dilakukan oleh Chennai Urban Population Study (CUPS) yang melaporkan bahwa prevalensi hipertensi pada pasien DM lebih besar tiga kali lipat yaitu 46,7\% dibandingkan dengan orang yang hanya menderita hipertensi saja sebesar $16,7 \% .^{7}$ Studi WESDR juga menunjukkan peningkatan prevalensi hipertensi setelah menderita DM 10 tahun pada pasien DM tipe 1 yang semula $17,3 \%$ menjadi $25,9 \%{ }^{8}$

Hipertensi kronis yang ditemukan pada penderita DM dapat memengaruhi kejadian dan keparahan retinopati diabetic sebesar 1-1,2 kali. Hal ini disebabkan keadaan hiperperfusi retina yang menyebabkan kerusakan pada kapiler retina yang menyebabkan peningkatan aliran darah dan memperburuk retinopati diabetik. Penelitian yang dilakukan UKPDS dengan follow-up selama 8,4 tahun 
menunjukkan bahwa pasien diabetes dengan hipertensi yang diberi obat antihipertensi dan dikontrol tekanan darah secara adekuat menurunkan resiko komplikasi mikrovaskular sebesar 37\%, risiko progresifitas retinopati diabetik berkurang sebesar $34 \%$, dan risiko memburuknya fungsi penglihatan sebesar $47 \%$ dibandingkan dengan pasien diabetes dengan tekanan darah yang tidak dikontrol secara adekuat. Pasien DM dengan hipertensi mempunyai kemampuan yang lebih rendah dalam mengatur aliran darah retina dibandingkan dengan orang yang tidak menderita diabetes. Sistem renin angiotensin terlibat dalam pengontrolan tekanan darah di retina yang terlihat pada proses patologis di retina. Pada penderita diabetes, hipertensi dapat menyebabkan kerusakan endothelial pada pembuluh darah retina dan meningkatkan ekspresi dari reseptor VEGF. VEGF dapat berikatan langsung dengan sel endothelial vaskular, menyebabkan peningkatan permeabilitas vascular dan membentuk neo vaskularisasi iskemik pada retinopati diabetik. VEGF juga akan menstimulasi ekspresi Intracellular Adhesion Molecule-I (ICAM-I) yang memicu terbentuknya ikatan antara leukosit dan endotel pembuluh darah. Ikatan ini menimbulkan kerusakan sawar darah retina, thrombosis, dan oklusi kapiler retina. Hal ini menunjukkan pengontrolan tekanan darah berpengaruh dalam menghambat onset kerusakan vaskular retina. ${ }^{10}$

\section{SIMPULAN}

Terdapat 187 (12,5\%) pasien retinopat diabetik di RSUP DR M Djamil Padang dari total pasien DM yang berjumlah 1500 orang pada periode Januari - Desember 2016.

Tingkat keparahan retinopati terbanyak ada pada stadium PDR.

Profil tingkat keparahan retinopati diabetik terbanyak ada pada pasien dengan hipertensi dengan tingkat keparahan pada stadium PDR.

\section{DAFTAR PUSTAKA}

1. Pandelaki K. Retinopati Diabetik. Dalam: Setiati S, Alwi I, Sudoyo A, Simadibrata M, Setiyohadi B, Syam AF, editor (penyunting). Buku ajar ilmu penyakit dalam jilid II. Edisi ke-6. Jakarta: Interna Publishing; 2014.hlm.1920-30.

2. Whiting DR, Georgata L, Weil C, Shaw J. Diabetes research and clinical practices. IDF diabetes atlas: global estimates of the prevalence of diabetes for 2011 and 2030. IDF: 2011; December:hlm.311-21.

3. Kementerian Kesehatan RI. Situasi dan Analisis Diabetes. Infodatin Pusat Data dan Informasi Kesehatan RI; 2013.

4. Soewondo P, Soegondo S, Suastika K, Pranoto A, Soeatmadji D, Tjokroprawiro A. The diabcare Asia 2008 study - outcomes on control and complications of type 2 diabetic patients in Indonesia. Med J Indones. 2008;19(4):235-43.

5. Pandelaki K, Suyono EA. Diabetes melitus di Indonesia. Dalam: Suyono EA, editor (penyunting). Buku ajar ilmu penyakit dalam Jilid III. Edisi ke-6. Jakarta: Interna Publishing; 2014. hlm.1910-19.

6. Fletcher E, Chong N. Retina. Dalam: Susanto D, editor (penyunting). Oftalmologi umum. Jakarta: EGC; 2009.hlm.185-8.

7. Deepa R, Shantirani C, Pradeepa R, Mohan V. Is the "Rule of Halves" in hypertension still valid? Evidence from the Chennai urban Population Study (CUPS). J AssocPhys India. 2003; 51:13537.

8. Klein R, Klein BEK, Moss SE, Davis MD, De Mets DL. The Wisconsin epidemiologic study of diabetic retinopathy II. Prevalence and risk of diabetic retinopathy when age at diagnosis is less than 30 years. Arch Ophthalmol 2008;102:520-26.

9. United Kingdom Prospective Diabetes Study group. Tight blood pressure control and risk of macrovascular and microvascular complications in Type 2 diabetes. UKPDS 38. Br Med J 1998; 317: 703-13.

10. Al-Sarraf AA, Al-Bannai SK, Al-Furaih AM, ElShazly MK. Prevalence and factors associated with diabetic retinopathy, a multi-centric study in Kuwait. Bull Alex Fac Med. 2010; 46(2)):99-108.

11. Fong DS, Aiello L, Gardner WT, King GL, Blankenship G, Cavallerano J Dea. Diabetic 
Retinopathy. American Diabetes Association. 2003; 26(1):226-9.

12. Semeraro F, Parrinello G, Cancarini A, Pasquini L, Zarra E, Cimino AEA. Predicitng The risk of diabetic retinopathy in type 2 diabetic patients. Journal of Diabetes and Its Complication. 2011 February; 292-7.

13. Tung $\mathrm{TH}$, Shih HC, Chen SJ, Chou P, Liu CM, Liu JH. A Community-based follow-up study on diabetic retinopathy among type 2 Diabetics in
Kinmen. European Journal of Epidemiology. 2005; 20: 317-23.

14. llery T, Vera S, Rares L. Prevalensi Retinopati diabetik di poliklinik ilmu kesehatan mata [skripsi]. Manado: Universitas Sam Ratulangi; 2013.

15. Harnita D. Hubungan antara lama menderita diabetes mellitus dengan derajat retinopati diabetik pada pasien diabetes mellitus tipe 2 (skripsi). Banda Aceh: Universitas Syah Kulala; 2013. 